\title{
JURIDICAL ANALYSIS ON CONSUMER PROTECTION IN SAFE AND HALAL FOOD DISTRIBUTION ${ }^{\Omega}$
}

\author{
Fifik Wiryani, Mokhammad Najih, and Abdul Haris \\ Faculty of Law and Faculty of Islamic Studies of University of Malang Muhammadiyah - Indonesia \\ E-mail: fwiryani2016@gmail.com
}

\begin{abstract}
As a Muslim majority country, it goes without saying that Indonesia protects the rights of Muslim consumers on risk-free and halal food distribution. This doctrinal juridical approach aims to analyze the regulation of the safe and halal food consumers' rights and their application to judicial decisions. The regulation of halal food distribution has provided a legal protection for the food consumers. The weakness of the regulation lies on the general criminal sanction without any specific minimum provision. A review of the court's verdict shows that the application of criminal sanction of the safe and halal food consumers' rights violations is still inconsistent. This is an implication of the general criminal sanction which gives free space to law enforcement to apply minimum penalty. This condition causes potentially violated regulation by food business actors.
\end{abstract}

Keywords: consumer protection, food distribution, judge's decision.

\begin{abstract}
Abstrak
Indonesia yang berpenduduk mayoritas muslim, wajar apabila menjamin secara hukum perlindungan hak-hak konsumen muslim terhadap peredaran pangan yang aman dan halal. Pendekatan yuridis doktrinal ini bermaksud untuk menganalisis pengaturan hak-hak konsumen pangan yang aman dan halal serta dalam penerapannya pada putusan pengadilan. Regulasi di bidang peredaran pangan aman dan halal telah memberikan perlindungan hokum kepada konsumen pangan. Kelemahan regulasi tersebut terdapat pada pengaturan ancaman sanksi pidana yang bersifat maskimum umum tanpa ada ketentuan miminum khusus. Telaah terhadap putusan pengadilan menunjukkan bahwa penerapan sanksi pidana terhadap pelanggaran hak-hak konsumen pangan yang aman dan halal masih tidak konsisten. Hal ini merupakan implikasi dari ancaman sanksi pidana maskimum umum, yang memberi ruang bebas kepada penegak hukum untuk menerapkan ancaman hukuman yang minimum. Kondisi ini dapat berdampak peraturan tidak dipatuhi oleh pelaku usaha bidang pangan.
\end{abstract}

Kata kunci: perlindungan konsumen, peredaran pangan, putusan hakim.

\section{Introduction}

Food is basic human needs in order to keep alive. ${ }^{1}$ It is human right to access food safely. ${ }^{2}$ The fulfillment of halal food is Government's duty to actualize a reliable and qualifi-

$\Omega \quad$ This paper is taken from "Penelitian Terapan Unggulan Perguruan Tinggi (PTUPT)" research, funded by DIPA Direktorat Jenderal Penguatan Riset dan Pengembangan, Kementerian Riset, Teknologi, dan Pendidikan Tinggi, No: SP DIPA-042.06.1.401516/2017, 6 December 2016.

1 Irna Nurhayati, "Efektivitas Pengawasan Badan Pengawas Obat Dan Makanan Terhadap Peredaran_Produk Pangan Olahan Impor Dalam Mewujudkan Perlindungan Konsumen”, Mimbar Hukum. Vol. 21 No. 2, June 2009, p. 203.

2 H. Kruse, "Food safety in an international perspective, Journal Für Verbraucherschutz und Lebensmittelsicherheit, Vol. 10 Issue 2, 2015, p. 105. ed human resources. Along with technological development, the rapid globalization and social change demands the provision of fast, appetizing, fresh-colored, fresh-smelled, attractive kind of food. To indulge consumers, producers compete to provide a wide variety of food in form of varied packaging, shapes, tastes, and colors with affordable price. They use many ways such as adding food additives. ${ }^{3}$

Besides food diversity, in the last decade there is a modern and Islamic oriented ${ }^{4}$-life-

3 Wiku Adisasmito, 2008, Analisis kebijakan Nasional MUI dan BPOM dalam Labeling Obat dan Makanan, Jakarta: Faculty of Public Health Universitas Indonesia, p.3.

4 Eka Dewi Setia Tarigan, "Pengaruh Gaya Hidup, Label Halal dan Harga Terhadap Keputusan Pembelian Kosm- 
style development which is halal food. Halal product is not only needed by Muslims but also urgent needs for non-Muslim. ${ }^{5}$ This can be seen from the fact of last 2010, global market demand for halal products has increased up to Rp 2,3 trillion. The increase of halal product is dominated by food and beverage products of $67 \%$, pharmaceutical products of $22 \%$, and cosmetic products of $11 \% .^{6}$ The survey conducted by $\mathrm{In}$ donesian Ulama Councils food, drugs and cosmetics research institution (LPPOM MUI) in Indonesia showed that people awareness on halal products increases. $^{7}$

Indonesia as a Muslim majority country does not only require risk-free but also halal food. ${ }^{8}$ In accordance with Islam beliefs, Muslim must consume halal and thoyyib products. For Muslim consumers, halal status in a product is a sensitive issue since it relates to their spiritual life that has a big consequence in either world or hereafter. ${ }^{9}$ It is explicitly regulated in Holy Qur'an, Al Baqarah:168. ${ }^{10}$

Consuming halal and thoyyib products for Muslim is a human rights (HAM) that is protected by Article 28E paragraph (1) and Article 29 paragraph (2) Constitution 1945, Human Rights Law No. 39 Year 2009, Law of Health No. 36 Year 2009, Law of Consumer Protection No. 8

etik Wardah Pada Mahasiswa Program Studi Manajemen Fakultas Ekonomi Universitas Medan Area, Medan”, Jurnal Konsep Bisnis dan Manajemen", Vol. 3 No. 1, November 2016, p. 47.

5 Asep Syarifuddin Hidayat, dan Mustolih Siradj. "Sertifikasi Halal dan Sertifikasi Non Halal, Jurnal Ahkam, Vol. XV No. 2, July 2015, p. 209.

6 Hafsari Aceh dan Nora Nailul Amal, “Persepsi Kelompok Masyarakat Non Muslim Terhadap Produk Kosmetik Berlabel Halal (Studi Deskriptif Kualitatif Tentang Persepsi Komunitas Mahasiswa Kristen "Persekutuan Mahasiswa Kristen" FISIP UNS Terhadap Produk Kosmetik Berlabel Halal)", Jurnal Komunikasi Massa, Vol. 1, Edition 2016, p. 2.

7 Lies Afroniyati, “Analisis Ekonomi Politik Sertifikasi Halal Oleh Majelis Ulama Indonesia”, Jurnal Kebijakan \& Administrasi Publik, Vol. 18 No. 1, May 2014, p. 39.

8 Kurniawan, Budi Sutrisno dan Dwi Martini, "Tanggung Jawab Pelaku Usaha Terhadap Pemberian Label Halal Pada Pada Makanan dan Minuman Perspektif Hukum Perlindungan Konsumen", Jurnal Penelitian Unram, Vol. 18 No. 1 , p. 81.

9 Nur Hadiati Endah, "Perilaku Pemberian Kosmetik Berlabel Halal Oleh Konsumen Indonesia”, Jurnal Ekonomi dan Pembangunan, Vol. 22 No. 1, 2014, p. 12.

10 Quran Surat 2:168: "Hai sekalian manusia, makanlah yang halal lagi baik dari apa yang terdapat di bumi, dan janganlah kamu mengikuti langkah-langkah Syaiton, karena sesungguhnya syaiton itu musuh nyata bagimu."
Year 1999, Law of Food No. 18 Year 2012, and Law of Halal Product Assurance No. 33 Year 2014. ${ }^{11}$

Halal concept cannot be separated from thoyyib. The halal concept refers to whether a product is allowed or not to be used based on Islamic principles while thoyyib concept means good" 12 which emphasizes on the product quality such as the nutrient content, cleanliness, safety and healthy..$^{13}$ Selvarajah Krishnan, et.al. stated Assurance system of halal has been acknowledged as a complete healthy system that includes Good Hygiene Practice (GHP), Good Manufacturing Practice (GMP) and Hazard Analysis Critical Control Point (HACCP) that have been existed before. ${ }^{14}$

Halal-certified products are beneficial for consumers and producers. ${ }^{15}$ The functions for consumers are: first, it prevents Muslim consumers from non-halal product; second, they feel secured; third, it protects consumer's body and soul from the forbidden products; and fourth, it provides the assurance of legal protection. ${ }^{16}$

The producers take advantages in terms of increasing consumers' trust and satisfaction, improving the company and marketing image and competitiveness. ${ }^{17}$ Those advantages are based on findings of Eka Dewi Setya Tarigan ${ }^{18}$ claiming that partially halal label provides positive and significant effect to the purchase of halal product among students. Meanwhile, research result by Hafsari Aceh and Nora Nailul $\mathrm{Amal}^{19}$ revealed that Christian students of $\mathrm{Fa}$ culty of Political Science in UNS perceive halal

\footnotetext{
11 K.N. Sofyan Hasan, "Kepastian Hukum Sertifikasi dan Labelisasi Halal Produk Pangan”, Jurnal Dinamika Hukum, Vol. 14 No. 2, May 2014, p. 227-228.

12 Ibid, p. 235.

13 Nur Hadiati Endah, loc.cit.

14 Selvarajah Krishnan, Mohamad Haniff, Mohd Aderis, Muhammad Nabil Azman, Mohammad Nazrin Azham Kamaluddin, "Halal Food: Study on Non-Muslim Acceptance", American Journal of Economics 2017, Vol. 7 No. 1, p. 41.

15 Asep Syarifuddin Hidayat dan Mustolih Siradj, op.cit, p. 201.

16 K.N. Sofyan Hasan, op.cit, p. 230.

17 Ibid, p. 229.

18 Eka Dewi Setia Tarigan, op.cit, p. 58. 19 Hafsari Aceh dan Nora Nailul Amal, op.cit, p. 15.
} 
label product with safety issue. ${ }^{20}$ Vloreen Nity Mathewa et al found that $92,8 \%$ non-Muslim consumers in Malaysia have positive response towards halal concept and want to buy halal food. ${ }^{21}$

In the event The $2^{\text {nd }}$ International seminar on Halalness and Safety of Food and Pharmaceutical Product in 2012, Deputy of Minister of Religion Affairs declared Indonesia's seriousness as the world center of halalness and the pioneer of halalness certification globalization. ${ }^{22}$ This commitment is showed in the increased halal products certification. In 2005, 969 products were certified and in 2014, 13.000 were halal-certified despite its only $8,39 \%$ of 155.000 circulated products. ${ }^{23}$ In 2016, among circulated halal products, 1319 food products were certification expired. ${ }^{24}$

Till present, there is no clear assurance of safety and halal products. ${ }^{25}$ According to National Consumer Protection Agency (BPKN), there are 4 food safety main problems, includeing: first, food poisoning due to damaged and contaminated food or food mixed with hazardous materials; second, the use of prohibited food additives; third, label condition which does not appropriate with the provision; and fourth, expired food. This study is in accordance with Dr. Margaret Chan (WHO Director General) statement that food safety is invisible problem and often being ignored. ${ }^{26}$ According to BPKN, the issue of label is less noticeable by consumers and producers because there are only $6,7 \%$ consumers who pay attention on it. In markets, a wide variety of products do not pro-

20 Ibid.

21 Vloreen Nity Mathewa, Ardiana Mazwa Raudah binti Amir Abdullah, dan Siti Nurazizah binti Mohamad Ismailc, "International Halal Conference", Procedia-Social and Behavioral Sciences, Vol. 121, 2014, p. 268.

22 Rahmah Maulidia, "Urgensi Regulasi dan Edukasi Produk Halal Bagi Konsumen”, Justitia Islamica, Vol. 10 No. 2, Juli-Desember 2013, p. 359.

23 Kementerian Agama Republik Indonesia, Without Years, Data Produk Tersertifikasi Halal LPPOM MUI, retrieved on: http://simbi.kemenag.go.id, Accessed on April $10^{\text {th }}, 2017$.

24 Endah, Nur Hadiati, loc.cit

25 Susilowati Suparto, "Harmonisasi dan Sinkronisasi Pengaturan Kelembagaan Sertifikasi Halal Terkait Perlindungan Konsumen Muslim Indonesia", Jurnal Mimbar Hukum, Vol. 28 No. 3, October 2016, p. 428.

26 H. Kruse, Loc. Cit. vide adequate information on the label. Lira Apriana Sari and friends found a food producer who intentionally sold some expired food products.

Recently, there are Korean instant noodle which contains pork ingredients, finger candies (a finger-shaped candy) which contain drugs, baby pacifier-shaped candies "Penguin Brand" alleged containing drugs, Rhodamin-B and formalin, salt mixed with alum, and synthetic rice. ${ }^{27}$ According to BPOM monitoring on $21^{\text {th }}$ of December 2016 in Bandung, 3.899 types of illegal and hazardous products (191.908 packages) have been found and destroyed which is worth 12,67 billion rupiahs. Those products are 3.744 medicine packages; 47.578 traditional medicine packages; 113.692 cosmetics, and 26.840 foods contaminated by formalin, borax and textile dyes; and 54 illegal health supplements. ${ }^{28}$

Unsafe food causes various health problems. Food containing harmful bacteria, viruses, parasites or chemicals induce 200 acute and chronic diseases from diarrhea until cancer. ${ }^{29}$ According to National Agency of Drugs and Food Control (BPOM) report in 2005, during 2004, 152 food poisoning outbreaks occurred and caused 7.295 people suffered from food poisoning and killed 45 people. In 2005, 61 cases of food poisoning outbreaks were found in which 8263 people suffered, 2251 people were sick and 3 people were dead. ${ }^{30}$

Law enforcement to protect food consumers can be done through implementation of administrative and criminal sanctions. As for criminal enforcement by court is not effective because the judge passed a minor sentences to the offenders. This condition shows the lack of consumers protection warranty of sustainable safe and halal food. It means the law enforcement for consumer protection warranty has not been effectively implemented. Accordingly, the criminal court decision is necessarily further examined for consumer protection.

\footnotetext{
27 BPOM, available on website: http://www.pom.go.id, Accessed on August $8^{\text {th }}, 2017$.

28 Ibid.

29 Kruse, loc.cit.

30 BPOM, loc.cit.
} 
This study discusses two problems; first, how is the regulation of consumer law protection to distribute safe and halal food?; second, how is the implementation in court decision by judges in criminal cases?

\section{Research Method}

This research uses juridical-doctrinal approach. The type of data is secondary data of primary and secondary law material. The data of primary law material are in form of regulations which govern food and consumer protection; and judges decision in food criminal case. The data of secondary law material is in form of journals, reference books, academic texts, articles, research result and the printed and online news media. The data collection is conducted using either printed or online literary review. The gathered data were then analyzed through content analysis and perspective analysis. ${ }^{31}$

\section{Discussion}

As above-mentioned, the discussion focuses on the main parts of this paper which includes regulations of consumers protection and its implementation in judges decision in court.

\section{Regulations of Law Protection on Safe and Halal Food Consumers}

In this study, the food consumers law protection is limited on the regulations of consumers rights and obligation, the food producers obligation in distributing food, and the prohibition and sanction. Those regulations relate to analysis of court decisions in this study.

\section{Food Consumer Rights}

Referring to Article 4 Consumer Protection Law (UUPK), the consumer's rights involve: first, rights of convenience, security, and safety in consuming goods or services; second, rights to choose goods or services, in accordance with the exchange rate and the promised condition; third, rights of valid, clear, and honest information about the condition and war-

31 Peter Machmud Marzuki, 2005, Penelitian Hukum, Jakarta: Prenada Media Group, p. 96-119. ranty of the goods or services; fourth, rights to be heard about their opinion and complaint over the goods and services; fifth, rights to get compensation when the goods or services are not appropriate with the agreement or how it should be. This regulation provides law protection to consumers especially for the safe and halal food. Therefore, if consumer rights are not fulfilled, they can claim their rights. In other words, it becomes producer's obligation, especially in this food producers cases.

\section{Producers Obligation of Food Distribution}

In order to fulfill consumer rights, producers must give label in food packages. The label must be written/printed firmly and clearly in Indonesian and contains the product name, ingredients, weight/net contents, the producer's name and address, the production date and code, expired date, license number, halal certificated for import products, allocation description, how to use, and other needed information for human health effects. This obligation relates to consumer rights in order to get the information about the products.

Furthermore, before distributing their products, the producers must gain distribution permit of BPOM and certification for halal product test from LPPOM-MUI. The products distribution permit and halal certification make a strategic role to guarantee halal and safe foods. Distribution of small and medium industry products in local market must have distribution permit of food household industry (PIRT) from local public health office. ${ }^{32}$ The certification process of safe and halal food can be seen through chart 1 and chart 2 .

Chart number 1 and 2 show that the obligation of safe and halal food producer is already well-managed well by the regulation. In addition, to make the food producers obey and implement the regulation, the law manages the prohibition and sanction in case of being violated for the sake of consumer protection.

32 Kurniawan, Budi Sutrisno, dan Dwi Martini, op.cit, p. 83. 
Chart 1. Food certification process by BPOM

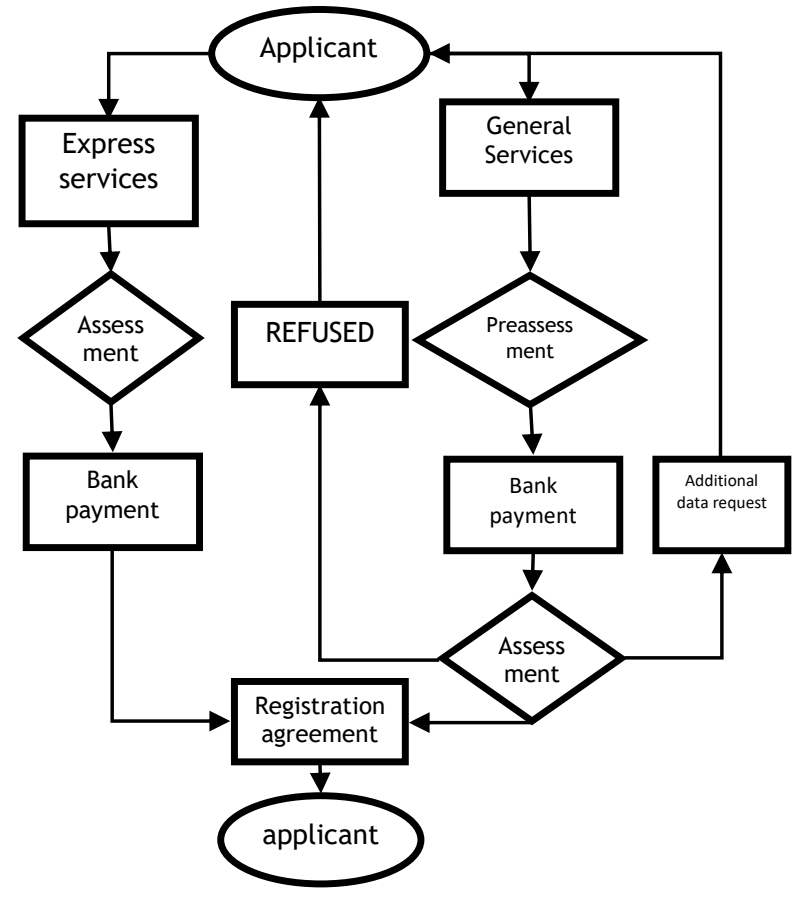

Sources : http://www.lacasacomics.com/

\section{Prohibition and Sanction on Packaged Food Producers}

There are 8 (eight) prohibitions on the packaged food producers: first, there is no label in packaged food that is written/printed clearly in Indonesian and the contents according to the BPOM rules; second, Using harmful package; third, using unidentified impact package without government agreement; fourth, opening package to re-pack for trade; fifth, deleting, pulling out, covering, replacing label, re-labeling/exchanging the expired date; sixth, Traded food is not based on the food safety and quality in the label; seventh, the incorrect or misleading content label ; and eighth, there is no distribution permit.

If the producers do not obey the regulation, they will be imposed by administrative and criminal sanction. The administrative sanction does not substitute the criminal sanction. Administrative sanction is coercive in terms of command, obligation or prohibition based on regulation. ${ }^{33}$ The implementation of adminis-

33 Ivan Fauzani Raharja, "Penegakan Hukum Sanksi Administrasi Terhadap Pelanggaran Perizinan”, Jurnal Inovatif, Vol. VII No. II, May 2014, p. 117. trative sanction application is a limitation for taking action. The administrative law enforcement has a function as a balancing instrument, prevention, the response to the prohibition in Law of Republic of Indonesia. ${ }^{34}$

Administrative sanction in food division is governed by: Consumer Protection Law (UUPK); jo Health Law; jo Food Law; and jo the Warranty of halal Products Law. Accordingly, there are 12 (twelve) administrative sanction types, as in table 1.

Table 1 shows that the formulation of administrative sanction is alternative not cumulative. The formulation limits the state administrative official to impose only one of the administrative sanction types. It indicates that the administrative sanction which functions as an instrument to manage, prevent, and cope the restricted actions in Law of Republic Indonesia is not well formulated.

The criminal sanction is regulated in Consumer Protection Law, Food Law, and The Halal Warranty Products Law. Its types are the primary and secondary crime. The primary crime consists of an imprisonment and the fine punishment. The regulation of primary crime sanctions is explained in Table 2.

According to table 2 by concerning the conceptual patterns, the formulation of the consumer protection law imposes the general maximum crime system without any specific minimum provision that employs the highest penalty. This formulation makes the law enforcement officer, especially public prosecutor, transparently arranges the indictment and demands as long as it does not beyond the maximum rules norm. Similarly, the judges can decide how long or big the sanction for defendant under the prosecutors demand and the maximum sanction threat. The formulation is relative not cumulative. It allows the public prosecutors and judges to choose between the imprisonment and the fines punishment, not both. This kind of formulation pattern indicates that

34 Amelia M. K. Panambunan, “Penerapan Sanksi Administratif dalam Penegakan Hukum Lingkungan di Indonesia”, Jurnal Lex Administratum, Vol. IV No. 2, February 2016, p. 93. 
Chart 2. Chart of registration process procedure of halal products LPPOM-MUI

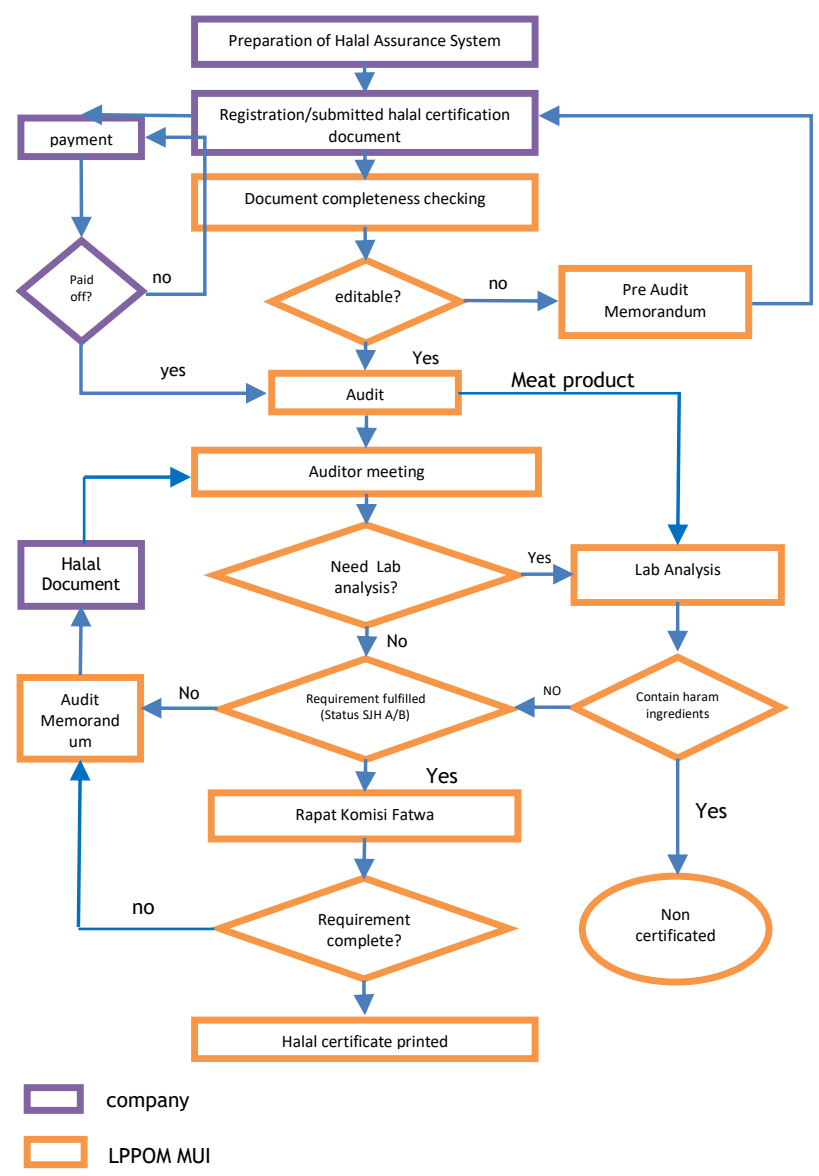

Sources:

http://www.halalmui.org/mui14/index.php/main/go_to_sec tion/58/1366/page/ 1
Sanction Imposition on the Violation of Safe and Halal Packaged Food Distribution Regulation in Court Verdict

As the object of this research, the verdict aims to review how the law enforcement employs the food consumer protection regulation to guarantee the implementation of consumer rights and the producer obligations. This verdict is the last fortress for the consumers and the producers to reach the justice assured by law. The author randomly selected 30 verdicts on the Supreme Court verdict website that handled the packaged food distribution crime. This verdict is an important representation of the consumer protection law enforcement.

Among the verdicts, the prosecutor con-victions that still apply the expired Law Num-ber 7 Year 1996 on food is found whereas the case happened after the new Law of food Num-ber 18 Year 2012 has been valid as the verdict Number 19/Pid./Sus/2013/PN.SKW. This shows that not all enforcers has understood the rule about the protection of food consumers yet. Related to the establishment of legal threat of Law by prosecutor and the decision by judge can be seen on the brief description of its comparison in table 3 .

Table 1. Ratio of Administrative sanction Violation Regulation in Food

\begin{tabular}{|c|c|c|c|c|}
\hline \multirow{2}{*}{ TYPES OF ADIMINSTRATIVE SANCTION } & \multicolumn{4}{|c|}{ TYPES OF ADMINISTRATIVE SANCTION REGULATION } \\
\hline & LAW 8/1999 & LAW 36/2009 & LAW 18/2012 & LAW 33/2014 \\
\hline Spoken Warning & $\mathbf{X}$ & $\mathbf{X}$ & $\mathbf{X}$ & $\Gamma$ \\
\hline Written Warning & $\mathbf{X}$ & $\mathbf{X}$ & $\mathrm{X}$ & $\Gamma$ \\
\hline Fines Imposition & $\mathbf{X}$ & $\mathbf{X}$ & 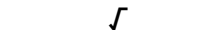 & $\Gamma$ \\
\hline Compensation Payment & $<200 \mathrm{~m}$ & $\mathbf{X}$ & $\Gamma$ & $\mathbf{X}$ \\
\hline Product-distributed withdrawal command & $\mathrm{X}$ & 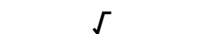 & $\Gamma$ & $\mathrm{X}$ \\
\hline Temporal prohibition of product distribution & $\mathbf{X}$ & $\mathbf{x}$ & $\Gamma$ & $\mathbf{X}$ \\
\hline Products seized to be abolished & $\mathbf{X}$ & 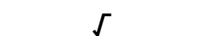 & $\mathbf{x}$ & $\mathbf{X}$ \\
\hline Temporarily stopping the production & $\mathrm{X}$ & $x$ & $\zeta$ & $\mathrm{X}$ \\
\hline Revocation of production permit & $\mathbf{X}$ & $\mathrm{x}$ & 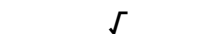 & $\mathbf{X}$ \\
\hline Revocation of circulation permit & $\mathbf{X}$ & 厂 & 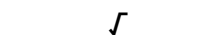 & $\mathrm{X}$ \\
\hline Revocation business permit; or & $\mathbf{X}$ & $\mathbf{x}$ & $\tau$ & $\mathbf{X}$ \\
\hline Revocation of halal certification & $\mathrm{X}$ & $x$ & $\mathrm{X}$ & 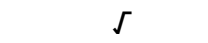 \\
\hline
\end{tabular}

Source: Law No. 8 Year 1999, Law No. 36 Year 2009, Law No. 18 Year 2012, and Law No. 33 Year 2014

From the table 3 we can see that: first, in some observed verdict, there are four variations used by the Judges in establishing the criminal sanction, they are: (a) the combina- tion of all sanction, imprisonment, fine, and additional penalty; (b) the combination of two sanctions, imprisonment and fine; (c) only one sort of sanction, imprisonment or fine with the 
Table 2. Ratio of Primary Sanction Regulation in Food Crime

\begin{tabular}{|c|c|c|c|}
\hline \multirow[b]{2}{*}{ Food Crime Type } & \multicolumn{3}{|c|}{ The highest Criminal Sanction } \\
\hline & $\begin{array}{c}\text { Law } \\
8 / 1999^{35} \\
\end{array}$ & $\begin{array}{c}\text { Law } \\
18 / 2010^{36} \\
\end{array}$ & $\begin{array}{c}\text { Law } \\
33 / 2014^{37} \\
\end{array}$ \\
\hline Imprisonment & $\begin{array}{c}\leq 5 \text { years } \\
\text { or }\end{array}$ & $\leq 10$ years or & $\begin{array}{c}<5 \text { years } \\
\text { or }\end{array}$ \\
\hline $\begin{array}{l}\text { Fines } \\
\text { Punishment }\end{array}$ & $\begin{array}{l}\leq \text { Rp. } 2 \\
\text { Billion }\end{array}$ & $\begin{array}{l}\leq \text { Rp. } 10 \\
\text { Billion }\end{array}$ & $\begin{array}{l}<\text { Rp. } 2 \\
\text { Billion }\end{array}$ \\
\hline
\end{tabular}

additional penalty; and (d) only the imprisonment or fine. Second, all public prosecutor indictments do not use the maximum threat compared to the provision of maximum sanction in the convicted article. There are 7 verdicts $(23,3 \%)$ where the prosecutor only indicts the fine penalty not the imprisonment, in the verdict Number 154/Pid.B/2013/PN.Trk.; Number 257/Pid.Sus/2014/PN.Bks; Number 51/Pid. Sus/2013/PN.Ung; Number 97/Pid.Sus/2014/P N.Pyh; Number 256/Pid.B/2013/PN.Trk.; Number 466/Pid.Sus/2014/PN.RHL; and Number $814 /$ Pid.Sus/2014/PN.Bjm. There is a minimum difference of the imprisonment of the food security between the prosecutor indictment and the maximum threat in the verdict Number 222/Pid.Sus/2013/PN.Jkt.Sel., it is about 1 year 6 months imprisonment of the maximum charges, 5 years (the prosecutor indictment is $30 \%$ of the maximum criminal threat). Furthermore, there is difference of imprisonment for the indictment about the provision of the halal food between the prosecutor indictment and the maximum threat included in the verdict Number 295/Pid.Sus/2013/PN.Jkt.Sel., on the criminal charge of 4 years imprisonment from the maximum charges, 5 years (the prosecutor indictment is $80 \%$ of maximum criminal threat). It is natural, because the halal food issue is a sensitive one for Muslim as the majority.

Third, from the scrutinized judgments, there is a tendency from the judge in deciding to charge the convict as the indictment and or

35 Law of Consumer Protection Number 8 year 1999 Article 62 and Article 63.

36 Law of Food 2012 Article 133, Article 134, Article 135, Article 136, Article 137 paragraph (1) and (2), Article 138, Article 139, Article 140, Article 141, Article 142, Article 143, Article 144, Article 145, Article 146 paragraph (1) and (2), Article 147 and Article 148 paragraph (1) and (2).

37 Law of Halal Product Warranty Number 33 year 2014 shorter than the prosecutor indictment. In the verdict Number 126/Pid/2014/PT. BDG, there is only one Judge decision $(3,3 \%)$ that charges the convict higher than the prosecutor indictment. Fourth, the higher discrepancy between the Judge decision with the maximum criminal threat is found in two verdicts, (a) the verdict from Nganjuk District Court Number 254/Pid.B/ 2014/PN.Njk. in which the maximum threat is based on Law Number 7 Year 1999: 5 years imprisonment or fine penalty, Rp 2 Billion; and based on Law Number 18 Year 2012: 2 years imprisonment or fine Rp4 Billion, and the Judge only decided the 15 days imprisonment $(4,1 \%)$ from the maximum criminal threat and the evidence is seized and destroyed. (b) Singkawang District Court Verdict Number 36/Pid.SUS/ $2013 /$ PN.SKW. in which the maximum threat is based on Law Number 7 Year 1999: 5 years imprisonment or Fine Rp2 Billion; and based on Law Number 7 Year 1996: 3 years imprisonment or Fine Rp360 Million; while the Judge only charges the criminal 23 days imprisonment $(6,3 \%)$ and the evidence is seized and destroyed.

If we see the patterns, some conditions potentially occur in litigation; first, there is a weakness in formulating the threat of criminal sanction in the Law that may become the chance for the prosecutor and judge to take the lighter penalty; second, both judge and the prosecutor do not have a well understanding about how important the protection of food consumer is as mentioned in the Law; third, the prosecutor and the judge considered that the criminal act towards the food security is same as the common criminal act whereas the criminal act towards the food security is actually related to humanity, economy, politics, and religion; fourth, there is a tendency that the prosecutor and the Judge sided the food producer based on the economic development consideration (like the consideration of security, investment, and others); fifth, it is potential where the Judge and the Prosecutor may be hard in gaining and collecting the evidence that may bring to the maximum sanction.; sixth, usually, in the lawsuits that involved the food producer and the public as the consumers, the position of the public is weaker, and seven- 
th, the tendency of public itself does not give a good attention towards the litigation about the violation of the consumers rights; eighth, besi- des the weaknesses above, the judicial mafia also potentially happens.

Table 3. The Comparison of Law and Food Criminal Law Enforcement in Judge Decision

\begin{tabular}{|c|c|c|c|c|c|c|}
\hline \multirow{2}{*}{$\begin{array}{c}\text { Kind of } \\
\text { Criminal Act }\end{array}$} & \multicolumn{3}{|c|}{$\begin{array}{l}\text { The Arrangement of Maximum } \\
\text { Criminal Sanction }\end{array}$} & \multirow{2}{*}{$\begin{array}{l}\text { Prosecutor } \\
\text { Indictment }\end{array}$} & \multicolumn{2}{|c|}{ Judge Decision } \\
\hline & $\begin{array}{l}\text { Law } \\
18 / 2012\end{array}$ & $\begin{array}{l}\text { Law } \\
8 / 1999\end{array}$ & $\begin{array}{c}\text { Law } \\
33 / 2014\end{array}$ & & $\begin{array}{l}\text { Minimum } \\
\text { Judgment }\end{array}$ & $\begin{array}{l}\text { Maximum } \\
\text { Judgement }\end{array}$ \\
\hline $\begin{array}{l}\text { Using the } \\
\text { forbidden food } \\
\text { additive (BTP)or } \\
\text { exceedingly use }\end{array}$ & $\begin{array}{l}\leq \text { 5years } \\
/ \quad \leq \\
\text { Rp } 10 \\
\text { Billion }\end{array}$ & $\begin{array}{l}\leq 5 \text { years } / \\
\leq \text { Rp. } 2 \\
\text { Billion }\end{array}$ & - & $\begin{array}{l}\text { Imprisonment: } 4- \\
12 \text { months } \\
\text { Fine: Rp.0-50 } \\
\text { Million }\end{array}$ & $\begin{array}{l}\text { Imprisonment: } 3 \\
\text { month } \\
\text { Fine: - }\end{array}$ & $\begin{array}{l}\text { Imprisonment: } 12 \\
\text { months } \\
\text { Fine: } \\
\text { Rp.50Million }\end{array}$ \\
\hline $\begin{array}{l}\text { Not Producing } \\
\text { and distributing } \\
\text { food under the } \\
\text { standard }\end{array}$ & $\begin{array}{l}\leq \text { 5years } \\
/ \quad \leq \\
\text { Rp. } 4 \\
\text { Billion }\end{array}$ & $\begin{array}{l}\leq \text { 5years / } \\
\leq \text { Rp. } 2 \\
\text { Billion }\end{array}$ & - & $\begin{array}{l}\text { Imprisonment: } 0 \text { - } \\
10 \text { month } \\
\text { Fine: Rp.5-50 } \\
\text { Million }\end{array}$ & $\begin{array}{l}\text { Imprisonment:2 } \\
3 \text { days } \\
\text { Fine: - }\end{array}$ & $\begin{array}{l}\text { Imprisonment: } 8 \\
\text { months } \\
\text { Fine: Rp. } 10 \\
\text { Million }\end{array}$ \\
\hline $\begin{array}{l}\text { Not having the } \\
\text { distribution } \\
\text { permit in } \\
\text { producing and } \\
\text { distributing the } \\
\text { food }\end{array}$ & $\begin{array}{l}\leq \text { 5years } \\
/ \quad \leq \\
\text { Rp. } 4 \\
\text { Billion }\end{array}$ & $\begin{array}{l}\leq \text { 5years / } \\
\leq \\
\text { Rp.2Billion }\end{array}$ & - & $\begin{array}{l}\text { Imprisonment: } 0 \text { - } \\
7 \text { months } \\
\text { Fine: } \operatorname{Rp} 5-15 \\
\text { Million }\end{array}$ & $\begin{array}{l}\text { Imprisonment: - } \\
\text { Fine: Rp4 } \\
\text { Million }\end{array}$ & $\begin{array}{l}\text { Imprisonment: } 4 \\
\text { months } \\
\text { Fine: Rp15 Million }\end{array}$ \\
\hline $\begin{array}{l}\text { The food is } \\
\text { different from } \\
\text { its label }\end{array}$ & $\begin{array}{l}\leq \text { 5years } \\
/ \quad \leq \\
\text { Rp. } 4 \\
\text { Billion }\end{array}$ & $\begin{array}{l}\leq \text { 5years / } \\
\leq \text { Rp. } 2 \\
\text { Billion }\end{array}$ & - & $\begin{array}{l}\text { Imprisonment: } 1 \text { - } \\
8 \text { months } \\
\text { Fine: Rp.0 }\end{array}$ & $\begin{array}{l}\text { Imprisonment: } \\
15 \text { days } \\
\text { Fine: - }\end{array}$ & $\begin{array}{l}\text { Imprisonment: } 6 \\
\text { months } \\
\text { Fine : - }\end{array}$ \\
\hline $\begin{array}{l}\text { producing and } \\
\text { distributing not } \\
\text { halal food }\end{array}$ & - & $\begin{array}{l}\leq 5 \text { years } / \\
\leq \\
\text { Rp.2Billion }\end{array}$ & $\begin{array}{l}\leq 5 \text { years } / \\
\leq \\
\text { Rp.2Billion }\end{array}$ & $\begin{array}{l}\text { Imprisonment: } 4 \\
\text { years } \\
\text { Fine: Rp.0 }\end{array}$ & $\begin{array}{l}\text { Imprisonment: } \\
32 \text { months } \\
\text { Fine: - }\end{array}$ & $\begin{array}{l}\text { Imprisonment: } 32 \\
\text { months } \\
\text { Fine : - }\end{array}$ \\
\hline
\end{tabular}

Source: Data processed from 30 Judges Decision of Food Crime In Indonesia

\section{Conclusion}

Reviewed from the legislation on the protection of save and halal food for consumer, the Law has secured the legal certainty on rights of safe and halal food consumer including BPOM and the certification of halal MUI through the LPPOM (Institution for Food Assessment of Drugs and Cosmetics) and the Fatwa Commission. It shows that the food security matter, safe and halal, is crucial because it relates to the life of people, either from its safety, economic, politics, or religion.

Law also provides sufficient provision to secure the safe and halal food consumer rights by giving the obligation of fulfilling the consumers' rights to the producers. Moreover the Law has given the provision on imprisonment for the criminal sanction, fine penalty and additional sanction if the condition is not obeyed by the producer.

Seeing from the establishment of the law, especially the sanction threat for the producers who commit a violation and crime, then the study of court verdicts in this observation shows some imbalances between the legislation and judge decision. It might happen because; the Law of consumer rights protection has not been understood well, it might cause the law enforcers consider the criminal act towards the field of food is same as the common crimes not as the serious violence. Besides, the criminal prosecution from the prosecutor that is far from the maximum certainty in Law and also the light criminal decision from the Judge potentially affect the food producers higher disobedience to the Law.

\section{Suggestion}

There are two suggestions: first, the changes of formulating the threat of criminal sanction in law on food. In addition, the consumers protection is needed to be particularly minimum and generally maximum by the cumulative implementation between the main sanction and the additional one; and second, the law enforcer must understand well the substance and the urgency of the Law on consumer rights protection to give the more justice. 


\section{References}

Aceh, Hafsari and Nora Nailul Amal. "Persepsi Kelompok Masyarakat Non Muslim Terhadap Produk Kosmetik Berlabel Halal (Studi Deskriptif Kualitatif Tentang Persepsi Komunitas Mahasiswa Kristen (Persekutuan Mahasiswa Kristen) FISIP UNS Terhadap Produk Kosmetik Berlabel Halal)". Jurnal Komunikasi Massa. Vol. 1. 2016. Pp. 1-20;

Adisasmito, Wiku. 2008. Analisis kebijakan $\mathrm{Na-}$ sional MUI dan BPOM dalam Labeling Obat dan Makanan. Jakarta: Faculty of Public Health Universitas Indonesia.

Afroniyati, Lies. “Analisis Ekonomi Politik Sertifikasi Halal Oleh Majelis Ulama Indonesia”. Jurnal Kebijakan \& Administrasi Publik. Vol. 18 Number 1. May 2014. Pp. 37-52;

BPOM. available on website: http://www.pom. go.id, Accessed on August $8^{\text {th }}, 2017$.

Endah, Nur Hadiati. "Perilaku Pemberian Kosmetik Berlabel Halal Oleh Konsumen Indonesia". Jurnal Ekonomi dan Pembangunan, Vol. 22 Number 1, 2014, Pp. 11-25. DOI: 10.14203/JEP.22.1.2014.25-39;

Hasan, K.N. Sofyan Hasan, "Kepastian Hukum Sertifikasi dan Labelisasi Halal Produk Pangan”. Jurnal Dinamika Hukum, Vol. 14 Number 2, may 2014, Pp. 227-238. DOI: 10.20884/1.jdh.2014.14.2.292;

Hidayat, Asep Syarifuddin and Mustolih Siradj. "Sertifikasi Halal dan Sertifikasi Non Halal”. Jurnal Ahkam, Vol. XV No. 2, July 2015, Pp. 99-210. DOI: 10.15408/ajis.v15 i2.2864;

Kementerian Agama Republik Indonesia. Without Years. Data Produk Tersertifikasi Halal LPPOM MUI. available on website: http://simbi.kemenag.go.id. Accessed on April 10 th 2017 ;

Krishnan, Selvarajah. Mohamad Haniff Hanafi Mohd Aderis. Muhammad Nabil Azman. Mohammad Nazrin Azham Kamaluddin. "Halal Food: Study on Non-Muslim Acceptance". American Journal of Economics, Vol. 7 Number 1, 2017. Pp. 41-45. DOI: 10.5923/j.economics.20170701.05. Pp. 41-45;

Kruse, H. "Food safety in an international perspective". Journal Für Verbraucherschutz Und Lebensmittelsicherheit. Vol. 10. 2015. Pp. 105-107. DOI: 10.1007/s00 003-015-0948-6;
Kurniawan. Budi Sutrisno and Dwi Martini, "Tanggung Jawab Pelaku Usaha Terhadap Pemberian Label Halal Pada Pada Makanan dan Minuman Perspektif Hukum Perlindungan Konsumen". Jurnal Penelitian Unram, Vol. 18 Number 1. Pp. 80-96.

Marzuki, Peter Macmud. 2005. Penelitian Hukum. Jakarta: Prenada Media Group;

Mathew, Vloreen Nity. Ardiana Mazwa Raudah binti Amir Abdullah and Siti Nurazizah binti Mohamad Ismailc. "Acceptance on Halal Food among Non-Muslim Consumers". Procedia-Social and Behavioral Sciences. Vol. 121. 2014. Pp. 262 - 271;

Maulidia, Rahmah. "Urgensi Regulasi dan Edukasi Produk Halal Bagi Konsumen". Justitia Islamica. Vol. 10 Number 2. July-December 2013. Pp. 359-390;

Nasution, Bahder Johan. "Upaya Penerapan Sanksi Administratif dan Perizinan sebagai Pembatasan terhadap Kebebasan Bertindak". Asy-Syir'ah Jurnal Ilmu Syari'ah dan Hukum. Vol. 48 Number 1. June 2014. Pp. 211-230. DOI: 10.14421/asysyir'ah.2014.\%25x;

Nurhayati, Irna. “Efektivitas Pengawasan Badan Pengawas Obat dan Makanan terhadap Peredaran Produk Pangan Olahan Impor dalam Mewujudkan Perlindungan Konsumen”. Mimbar Hukum. Vol. 21 Number 2. June 2009. Pp. 203-222. DOI: 10.22146/ jmh.16265;

Panambunan, Amelia M K. "Penerapan Sanksi Administratif dalam Penegakan Hukum Lingkungan di Indonesia". Jurnal Lex Administratum. Vol. IV Number 2. February 2016. Pp. 93-101;

Raharja, Ivan Fauzani. "Penegakan Hukum Sanksi Administrasi Terhadap Pelanggaran Perizinan". Jurnal Inovatif. Vol. VII Number II. May 2014. Pp. 117-138;

Suparto, Susilowati. "Harmonisasi Dan Sinkronisasi Pengaturan Kelembagaan Sertifikasi Halal Terkait Perlindungan Konsumen Muslim Indonesia". Jurnal Mimbar Hukum. Vol. 28 Number 3. October 2016. Pp. 427-438. DOI: 10.22146/jmh.16674;

Tarigan, Eka Dewi Setia. "Pengaruh Gaya Hidup. Label Halal dan Harga Terhadap Keputusan Pembelian Kosmetik Wardah Pada Mahasiswa Program Studi Manajemen Fakultas Ekonomi Universitas Medan Area. Medan". Jurnal Konsep Bisnis dan Manajemen". Vol. 3 Number 1. November 2016. Pp. 47-61. 
